\title{
Analisis Investigasi Faktor-Faktor Yang Mempengaruhi Kemampuan Perusahaan Dalam Pembayaran Dividen
}

\author{
Dyah Rosna Yustanti Toin* \\ Sutrisno $^{\star *}$
}

\section{Abstract}

There are two conflicting interests in the use of corporate profits, the first for the payment of dividends to shareholders, second for the benefit of corporate development. For that reason managements should take the form of dividend policy how much dividend to be distributed and how much profit will be used for the development of the company (retained earnings).

This study aims to examine the factors that affect the ability of companies in the payment of dividends. Proxy for ability to pay dividends is measured with Dividend Payout Ratio (DPR) as dependent variable, while the independent variables are profitability $(X I)$, liquidity $(X 2)$, Leverage (X3), and the Firm's growth (X4)

The results showed that the profitability variable has a statistically significant and positive correlation with the ability to pay dividends. Likewise, the variable of firm's growth is statistically also has negative and significant correlation with the dividend payout ratio. While the variables liquidity and leverage have statistically not significant correlation with the dividend payment.

It can be concluded that in this study there are two variables that support the hypothesis that profitability and firm's growth, while two other variables do not support the hypothesis that liquidity and leverage.

Keyword: Dividend payout ratio, Liquidity, leverage, firm growth

\section{Pendahuluan}

Secara umum tujuan Investor dalam berinvestasi adalah memaksimalkan return, tanpa melupakan faktor resiko investasi yang harus dihadapinya. Return merupakan imbalan atas keberanian investor menanggung risiko atas investasi yang dilakukannya. Baik itu return yang berupa capital gain maupun dividen. Dividen merupakan bagian laba yang diperuntukkan bagi pemegang saham sesuai dengan proporsi mereka dari jenis modal tertentu (IAI,2004:23.2).

Dosen Amikom Cipta Darma Surakarta.

** Dosen Fakultas Ekonomi UII. 
Pembagian dividen diatur dalam kebijakan dividen, kebijakan tersebut berisi tentang besarnya laba yang akan dibagikan sebagai dividen dan laba yang akan ditahan (Husnan,1994:331). Kebijakan dividen yang fleksibel mencakup bentuk dividen yang akan dibagikan kepada para pemegang saham (IAI,2004:21.7). Bentuk-bentuk dividen dapat berupa dividen tunai, dividen property, dividen skrip, dividen likuidasi dan dividen saham. Dalam penelitian ini akan dilihat mengenai pembagian dividen dalam bentuk dividen tunai.

Dalam kebijakan dividen melibatkan dua pihak yang berkepentingan dan saling bertentangan, yaitu kepentingan pemegang saham atas dividen dan kepentingan perusahaan atas laba ditahan yang akan digunakan untuk diinvestasikan kembali. Sehingga diperlukan kebijakan dividen yang memenuhi harapan investor, yaitu untuk mendapatkan dividen dimana pada saat yang sama tidak menghambat pertumbuhan perusahaan.

Besar kecilnya dividen yang dibagikan kepada pemegang saham tergantung pada besarnya laba yang diperoleh perusahaan karena dividen dibagikan dari laba bersih. Selain itu untuk menetapkan apakah perusahaan masih mampu membayar dividen tergantung posisi likuiditas karena dari kas yang ada di perusahaan dapat diketahui apakah perusahaan benar-benar memiliki dana untuk memenuhi kewajibannya, termasuk juga untuk membayar dividen. Menurut Mawarsari (2007) hal ini disebabkan karena sering kali keuntungan yang diperoleh perusahaan digunakan untuk membeli aktiva yang dibutuhkan sehingga tingkat likuiditasnya menjadi rendah. Perusahaan yang mempunyai laba tinggi tetapi sedang dalam tahap ekspansi akan mempunyai likuiditas yang rendah karena laba digunakan untuk membiayai ekspansi. Beberapa perusahaan yang mempunyai hutang juga akan tetap mempunyai kewajiban membayar beban bunga sehingga mengurangi kemampuan membayar dividen.

Untuk itu investor harus memiliki kemampuan untuk memprediksikan kemampuan perusahaan dalam membayar dividen sehingga investor dapat mengambil keputusan investasi yang tepat dan menguntungkan. Apabila seorang investor tidak dapat memprediksi tingkat pengembalian investasi yang berupa dividen maka akan sangat tidak menguntungkan bagi investor itu sendiri karena tidak dapat mengambil keputusan dengan tepat.

Mengingat akan arti penting laba, baik bagi perusahaan maupun pihak investor, dimana perusahaan berkepentingan untuk mendonasi ekspansi dan meningkatkan pertumbuhan perusahaan, sementara di lain pihak investor mengharapkan adanya pembagian keuntungan atas laba yang diperolehnya. Perusahaan harus bisa membuat sebuah kebijakan yang optimal. Kebijakan yang diambil harus bisa memenuhi kepentingan kedua belah pihak dimana perusahaan tetap bisa memenuhi kebutuhan dana, sedangkan pihak investor memperoleh apa yang dïnginkan, sehingga investor tidak mengalihkan ke perusahaan lain. 


\section{Kajian Teori}

Sebagian laba yang diperoleh perusahaan dalam operasinya akan dibagikan kepada pemegang saham dan sebagian ditahan untuk diinvestasikan pada proyek yang menguntungkan. Maka dari itu manajer keuangan harus dapat mengambil keputusan berapa besarnya laba yang harus dibagikan kepada pemegang saham dan laba yang ditahan untuk membiayai pertumbuhan perusahaan? Keputusan tersebut akan mempunyai pengaruh yang menentukan terhadap nilai perusahaan. Besarnya laba yang dibagikan kepada pemegang saham disebut dividen. Jumlah dividen yang akan dibagikan diusulkan oleh Dewan Direksi dan disetujui di dalam Rapat Umum Pemegang Saham (RUPS).

\section{Pengertian Kebijakan Dividen}

Menurut Waskito (2007), awalnya kebijakan dividen merupakan keputusan perusahaan mengenai berapa dividen kas (cash dividend) yang harus dibayarkan dan berapa kali deviden tersebut akan dibayarkan dalam satu tahun. Saat ini pengertian kebijakan dividen menyangkut keputusan yang lebih beragam seperti; apakah kas akan didistribusikan dengan cara stock repurchases (pembelian kembali saham) atau lewat dividen kas, apakah perusahaan lebih mementingkan kenaikan harga saham dengan cara menahan laba lebih banyak atau membagikan dividen yang lebih besar, bagaimana menjaga keseimbangan antara kepentingan investor individual yang pajak atas dividennya tinggi dan investor institusional yang pajak atas dividennya rendah.

Kebijakan dividen adalah kebijakan yang mengatur apakah dividen dibagikan, bagaimana suatu dividen dibagikan, berapajumlahnominal dividen per lembarsaham, kapan saham dibagikan, maupun hal-hal lain yang berkenaan dengan karakteristik pembagian dividen. Pihak perumus kebijakan dividen adalah manajemen perusahan, dan kemudian kebijakan tersebut akan didiskusikan dalam rapat umum Pemegang Saham (RUPS). Apabila ternyata kebijakan dividen tersebut disetujui oleh sebagian besar dewan komisaris, maka barulah kebijakan itu sah untuk dijalankan.

\section{Teori Kebijakan Dividen}

\section{1.) Dividen Irrelevance}

Modigliani dan Miller (1961) berpendapat bahwa di dalam kondisi keputusan investasi yang given, pembayaran dividen tidak berpengaruh terhadap 'kemakmuran pemegang saham. Lebih Ianjut MM juga berpendapat bahwa nilai perusahaan dibentuk oleh earning power dari assets perusahaan. Dengan demikian, nilai perusahaan ditentukan oleh keputusan investasi. Sementara itu keputusan apakah laba yang diperoleh akan dibagikan dalam bentuk dividen atau akan ditahan tidak mempengaruhi nilai perusahaan. 
Hal penting dari pendapat Modigliani dan Miller adalah bahwa pengaruh pembayaran dividen terhadap kemakmuran pemegang saham akan diimbangi dengan jumlah yang sama dengan cara pembelanjaan atau pemenuhan dana yang lain. Dalam kondisi keputusan investasi yang given, maka apabila perusahaan membagikan dividen kepada pemegang saham, perusahaan harus mengeluarkan saham baru sebagai pengganti sejumlah pembayaran dividen tersebut. Dengan demikian kenaikan pendapatan dari pembayaran dividen akan diimbangi dengan penurunan harga saham sebagai akibat penjualan saham baru. Dengan demikian apakah laba yang diperoleh dibagikan sebagai dividen atau akan ditahan dalam bentuk laba ditahan tidak mempengaruhi kemakmuran pemegang saham.

\section{2.) Bird in the Hand Theory}

Salah satu asumsi dalam pendekatan Modligiani-Miller (1961) adalah bahwa kebijakan deviden tidak mempengaruhi tingkat keuntungan yang disyaratkan oleh Investor. Sementara itu Lintner (1956) berpendapat bahwa kentungan yang disyaratkan akan meningkat sebagai akibat penurunan pembayaran deviden. Investor lebih merasa aman untuk memperoleh pendapatan berupa pembayaran deviden daripada menunggu capital gain.

Sementara itu MM berpendapat dan telah dibuktikan secara matematis bahwa investor merasa sama saja apakah menerima deviden saat ini atau menerima capital gain di masa datang. Sehingga tingkat keuntungan yang diisyaratkan, tidak dipengaruhi oleh kebijakan deviden. Pendapat Lintner ini oleh ModligianiMiller diberi nama the-bird-in-the-hand fallacy. Lintner (1956) beranggapan bahwa investor memandang satu burung di tangan lebih berharga daripada seribu burung di udara. Sementara itu MM berpendapat bahwa tidak semua investor berkeinginan untuk menginvestasikan kembali deviden mereka di perusahaan yang sama atau sejenis dengan memiliki rasio yang sama, oleh sebab itu tingkat risiko pendapatan mereka di masa datang bukannya ditentukan oleh kebijakan deviden, tetapi ditentukan oleh tingkat risiko investasi baru.

\section{3.) Tax Differential Theory}

Menurut Brigham dan Gapenski (199:439) ada tiga alasan yang berkaitan dengan pajak untuk beranggapan bahwa investor mungkin lebih menyukai pembagian deviden yang rendah daripada yang tinggi, yaitu (1) Pendaftaran deviden dikenakan pajak lebih tinggi dibandingkan dengan tarif pajak keuntungan modal. Oleh karena itu, investor yang kaya (yang memiliki sebagian besar saham dan menerima sebagian besar deviden yang dibayarkan) mungkin lebih suka perusahaan menahan dan menanamkan kembali laba dalam perusahaan. Pertumbuhan laba mungkin dianggap menghasilkan kenaikan harga saham, dan keuntungan modal yang pajaknya rendah akan menggantikan deviden yang pajaknya tinggi, (2) Pajak atas keuntungan tidak dibayarkan sampai saham 
terjual. Karena adanya efek nilai waktu, satu dolar pajak yang dibayarkan di masa mendatang mempunyai biaya efektif yang lebih rendah daripada satu dolar yang yang dibayarkan hari ini, dan (3) Jika selembar saham dimiliki oleh seseorang sampai orang tersebut meninggal, sama sekali tidak ada pajak keuntungan modal yang terhutang, ahli waris yang menerima saham itu dapat menggunakan nilai saham pada hari kematian sebagai dasar biaya mereka, dengan demikian mereka terhindar dari pajak keuntungan modal.

\section{Penelitian Terdahulu}

Penelitian mengenai kebijakan dividen telah dilakukan oleh peneliti-peneliti sebelumnya. Penelitian tersebut diantaranya adalah:

Mawarsari (2007), penelitian ini mengukur pengaruh Profitabilitas, Likuiditas, Leverage, dan Pertumbuhan perusahaan terhadap Dividend Payout Ratio pada perusahaan manufaktur di BEJ, menyimpulkan bahwa Profitabilitas, Likuiditas, dan Pertumbuhan perusahaan terbukti secara empiris dapat memprediksi dividen, sedangkan hanya Hutang yang tidak terbukti secara empiris dapat memprediksi dividen yang akan dibagikan perusahaan.

Ernawati (2007), pada penelitiannya yang menggunakan variabel profitabilitas, likuiditas, leverage (hutang), kesempatan investasi, meneumkan bahwa secara bersama-sama faktor-faktor tersebut mempengaruhi secara signifikan dengan melihat tingkat probabilitasnya 0.0033 dibawah tingkat signifikansi yang digunakan yaitu $(0.05)$. meskipun demikian hanya Profitabilitas dan Leverage yang terbukti sesuai dengan hipotesisnya.

Waskito (2007), pada penelitian ini menggunakan rasio Investasi, Likuiditas, Profitabilitas, dan Pertumbuhan yang secara simultan berpengaruh signifikan terhadap Dividen Payout Ratio (Y), hal ini dibuktikan dengan hasil probabilitas lebih kecil dari $0,05(0,000<0,05)$. Namun hanya variabel Investasi dan Profitabilitas yang hipotesisnya dapat diterima.

\section{Hipotesis}

Kami akan menguji beberapa faktor yang mempengaruhi kebijakan Dividend Payout Ratio yang terddiri dari variabel Profitabilitas, Likuiditas, Hutang, dan Pertumbuhan perusahaan.

' $\mathrm{H}_{1}$ : Profitabilitas mempunyai korelasi positif dengan kemampuan perusahaan dalam pembayaran dividen.

Dividen merupakan sebagian dari laba bersih yang diperoleh perusahaan, dan dividen akan dibagikan jika perusahaan memperoleh keuntungan. Keuntungan yang layak dibagikan kepada para pemegang saham, adalah keuntungan setelah perusahaan memenuhi seluruh kewajiban tetapnya yaitu beban bunga dan pajak. Oleh karena dividen diambil dari keuntungan bersih yang diperoleh perusahaan, 
maka keuntungan tersebut akan mempengaruhi besarnya dividend payout ratio. Perusahaan yang memperoleh keuntungan cenderung akan membayar porsi keuntungan yang lebih besar sebagai dividen.

$\mathrm{H}_{2}$ : Likuiditas mempunyai korelasi positif dengan kemampuan perusahaan dalam pembayaran dividen.

Likuiditas perusahaan menunjukkan kemampuan perusahaan mendanai operasional perusahaan dan melunasi kewajiban jangka pendeknya. Oleh karena itu perusahaan investee yang memiliki likuiditas tinggi maka memungkinkan pembayaran dividen lebih besar pula.

$\mathrm{H}_{3}$ : Hutang mempunyai korelasi negatif dengan kemampuan perusahaan dalam pembayaran dividen.

Perusahaan yang berisiko akan memberikan dividen yang rendah, dengan maksud mengurangi ketergantungan akan pendanaan secara eksternal. Struktur permodalan perusahaan akan membandingkan antara permodalan dari kreditor dan pemegang saham. Struktur permodalan yang lebih tinggi dimiliki oleh hutang menyebabkan pihak manajemen akan memprioritaskan pelunasan kewajiban terlebih dahulu sebelum membagikan dividen. Perusahaan yang memiliki rasio hutang lebih besar seharusnya membagikan dividen lebih kecil karena laba yang diperoleh digunakan untuk melunasi kewajiban.

$\mathrm{H}_{4}$ : Pertumbuhan perusahaan mempunyai korelasi negatif dengan kemampuan perusahaan dalam pembayaran dividen.

Semakin tinggi tingkat pertumbuhan suatu perusahaan, akan semakin besar tingkat kebutuhan dana untuk membiayai ekspansi. Semakin besar kebutuhan dana di masa yang akan datang, akan memungkinkan perusahaan menahan keuntungan dan tidak membayarkannya sebagai dividen. Oleh karenanya potensi pertumbuhan perusahaan menjadi faktor penting yang menentukan kebijakan dividen, dan sebagai indikator pertumbuhan adalah perubahan total asset

\section{Metode Penelitian}

\section{Sampel}

Sampel penelitian dilakukan dengan menggunakan metode purposive sampling. Dengan metode tersebut hanya objek yang memenuhi kriteria yang digunakan dalam pemilihan sampel, yaitu perusahaan panufaktur yang terdaftar di Bursa Efek Indonesia (BEI) yang secara konsisten membagikan dividen kas selama tahun penelitian yaitu tahun 2005 sampai tanggal 31 Desember 2009.

\section{Variabel Penelitian dan definisi Variabel}

1. Variabel dependen $(\mathrm{Y})$ adalah variabel yang terikat dengan variabel lain dan 
hasilnya ditentukan oleh variabel independen. Dalam penelitian ini variabel dependennya adalah devidend payout ratio (DPR), yang formulasinya adalah:

$$
D P R=\frac{\text { Dividen per lembar saham }}{\text { Labar per lembar saham }}
$$

2. Variabel independen yaitu variabel yang tidak terikat oleh variabel lain. Variabel independen dalam penelitian ini terdiri dari: Profitabilitas $\left(X_{1}\right)$, Likuiditas $\left(\mathrm{X}_{2}\right)$, Hutang $\left(\mathrm{X}_{3}\right)$, Pertumbuhan Perusahaan $\left(\mathrm{X}_{4}\right)$.

a. Profitabilitas kemampuan perusahaan untuk menghasilkan laba dapat diukur dengan menggunakan rasio Return On Investment (ROI). Melalui ROI akan ditunjukkan seberapa banyak laba bersih yang bisa diperoleh dari seluruh kekayaan yang dimiliki perusahaan.

$$
R O I=\frac{\text { Laba setelah pajak }}{\text { Total Aktiva }}
$$

b. Likditas dapat diukur dengan menggunakan Current Ratio, ratio ini akan mengukur seberapa jauh aktiva lancar perusahaan bisa dipakai untuk memenuhi kewajiban lancar.

$$
C R=\frac{\text { Aktiva Lancar }}{\text { Hutang Lancar }}
$$

c. Leverage adalah seberapa besar kekayaan perusahaan dibelnajai oleh hutang. Untuk mengukur tingkat leverage dapat dinituing dengan iēverage ratio yang paling umum digunakan yaitu Debt to Equity Ratio, rasio ini menunjukkan rasio antara total hutang dan total asset.

$$
D E R=\frac{\text { Total Hutang }}{\text { Total Equitas }}
$$

d. Pertumbuhan perusahaan merupakan salah satu faktor yang berpengaruh terhadap dividen, pertumbuhan perusahaan dapat diukur melalui pertumbuhan aktiva dari tahun ke tahun. 


$$
\text { Growth }=\frac{\text { Aset }_{t}-\text { Aset }_{t-1}}{\text { Aset }_{t-1}}
$$

\section{3). Uji Hipotesis}

Analisis data dilakukan dengan menggunakan analisis regresi berganda. Adapun rumusan regresi dapat dirumuskan sebagai berikut:

$$
Y=\alpha+\beta 1 X_{1}+\beta_{2} X_{2}+\beta 3 X_{3}+\beta 4 X_{4}+e
$$

Dimana:

$\mathrm{Y}$ : Dividend payout ratio

$\alpha$ : Konstanta

$\beta$ : Koefisien Regresi

$\mathrm{X}_{1}$ : Profitabilitas

$\mathrm{X}_{2}$ : Likuiditas

$\mathrm{X} 3: \mathrm{DER}$

$\mathrm{X}_{4}$ : Pertumbuhan Perusahaan

e : Variabel residual

Metode pengujian hipotesis yang digunakan dalam penelitian ini adalah uji $\mathrm{F}$ (simultan) dan uji t (parsial).

- Uji F dimaksudkan untuk menguji signifikansi secara serempak atau bersama-sama pengaruh variabel independen terhadap variabel dependen. Uji ini digunakan apakah variabel independen ROI, Current Ratio, Debt to Equity dan Growth berpengaruh signifikan secara serempak terhadap variabel dependen Dividen Payout Ratio.

-_. Jji tidimaksudkan uintuk menguji signifikasi secara parsial pengaruh masingmasing variabel independen terhadap variabel dependen. Uji ini digunakan untuk menguji apakah masing-masing variabel independen ROI, Current Ratio, Debt to Equity dan Growth berpengaruh signifikan terhadap Dividen Payout Ratio.

\section{4). Pengujian hipotesis}

Uji hipotesis yang dilakukan pada penelitian ini yaitu dengan melihat apakah ROI, CD, DER dan GROWTH mempengaruhi deviden payout ratio. Dari hasil olah data dengan menggunakan SPSS 15 diperoleh hasil sebagai berikut:

\section{Uji F}


Dyah Rosna Yustanti Toin \& Strisno, Analisis Investigasi Faktor-faktor yang.....

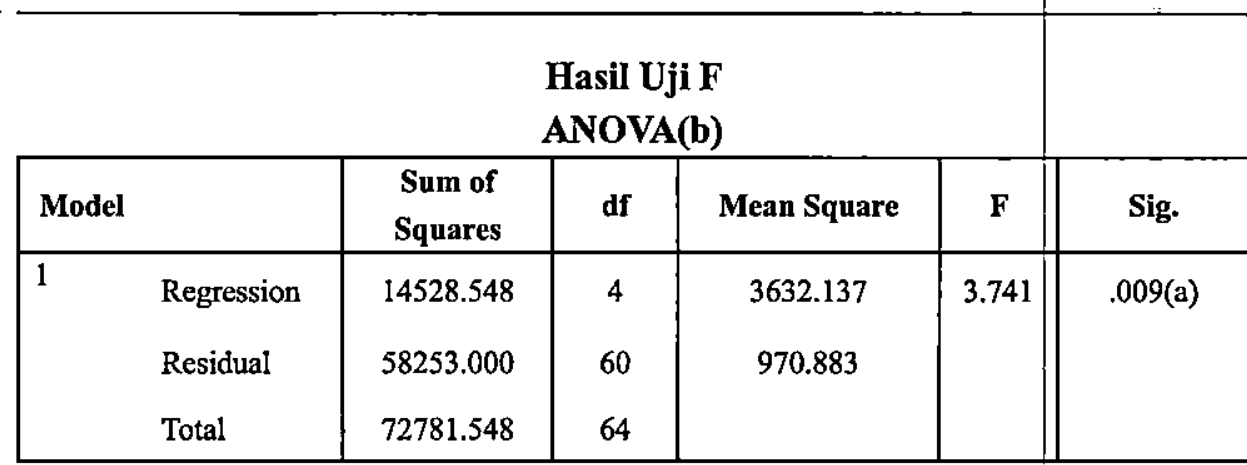

a Predictors: (Constant), GROWTH, ROI, CR, DTA

b Dependent Variabel: DPR

Dilihat dari $\mathrm{F}$ statistic menunjukkan nilai sebesar 3,741 dengan nilai signifikansi dibawah 0,05 sebesar 0,009 artinya ROI, CR, DER, dan GROWTH secara simultan berpengaruh signifikan terhadap dividend payout ratio secara keseluruhan.

Uji t

Hasil Uji t

\begin{tabular}{|l|c|c|c|}
\hline Variabel & Coefficients & StandartEror & Sig \\
\hline ROI & 1,548 & 0,432 & 0,001 \\
CR & -1.348 & 2,536 & 0,597 \\
DTA & 8,278 & 6,442 & 0,204 \\
GROWTH & $-3,245$ & 1,541 & 0,002 \\
\hline
\end{tabular}

Berdasar hasil regresi di atas menunjukkan bahwa variabel ROI memiliki nilai signifikansi dibawah 0,05 yaitu sebesar 0,001 sehingga Ho ditolak berarti Ha diterima. Hal ini menunjukkan bahwa variabel ROI berpengaruh signifikan terhadap dividend payout ratio.

Variabel CR memiliki nilai signifikansi diatas 0,05 yaitu sebesar 0,597 sehingga Ho diterima dan Ha ditolak. Hal ini menunjukkan bahwa variabel CR tidak berpengaruh signifikan terhadap dividend payout ratio.

Variabel DER memiliki nilai signifikansi diatas 0,05 yaitu sebesar 0,204 sehingga Ho diterima dan Ha ditolak. hal ini menunjukkan bahwa variabel DTA tidak berpengaruh signifikan terhadap dividend payout ratio.

Variabel Growth memiliki nilai signifikansi dibawah 0,05 yaitu sebesar 0,002 . Hal ini menunjukkan bahwa variabel Growth berpengatuh signifikan terhadap dividend payout ratio, maka dapat ditarik kesimpulan bahwa Ho ditolak dan Ha diterima, dan karena itu hipotesisnya berpengaruh negatif maka Ha diterima. 


\section{Pembahasan}

\section{Hipotesis 1}

Hipotesis pertama menyatakan bahwa profitabilitas berkorelasi positif dengan pembayaran dividen. Hasil pengujian dengan menggunakan menunjukkan bahwa profitabilitas berpengaruh secara signifikan terhadap dividen, dengan melihat taraf signifikansi yaitu sebesar 0,001 dimana nilai signifikan $0,001<0,05$, artinya bahwa profitabilitas perusahaan yang diwakili oleh ROI berpengaruh terhadap dividen yang dibagikan perusahaan. Sedangkan hubungan yang ditunjukkan oleh koefisien regresi adalah positif 1,548 artinya adalah semakin tinggi profitabilitas maka semakin tinggi pula dividen yang dibagikan perusahaan. Sehingga hipotesis pertama diterima yaitu semakin tinggi profitabilitas maka semakin besar kemampuan perusahaan dalam pembayäran dividen. Dividen berasal dari sebagian laba bersih perusahaan yang dicerminkan dengan profitabilitas perusahaan, oleh karena itu perusahaan yang memperoleh keuntungan tinggi akan membayar porsi keuntungan yang lebih besar sebagai dividen. Penelitian ini sejalan dengan penelitian Mawarsari (2007), Ernawati (2007), dan Waskito (2007), yang membuktikan bahwa Profitabilitas mempengaruhi dividend payout ratio.

\section{Hipotesis 2}

Hipótesis kedua menyatakan likuiditas berkorelasi positif pembayaran deviden. Hasil pengujian dengan menggunakan regresi linear menunjukkan bahwa likuiditas tidak berpengaruh secara signifikan terhadap dividen, artinya bahwa likuiditas yang diwakili oleh CR tidak berpengaruh terhadap dividen yang dibagikan perusahaan. Sedangkan hubungan yang ditunjukkan oleh koefisien regresi adalah negatif $-1,348$ artinya adalah semakin tinggi likuiditas maka semakin rendah dividen yang dibagikan perusahaan. Sehingga hipotesis ditolak yaitu semakin tinggi likuiditas maka semakin rendah kemampuan perusahaan dalam pembayaran dividen.

Perusahaan yang sedang mengalami pertumbuhan dan profitable akan memerlukan dana yang cukup besar guna membiayai investasinya, sehingga dimungkinkan akan menjadi rendah tingkat likuiditasnya karena dana yang diperoleh lebih banyak diinvestasikan pada aktiva tetap dan aktiva lancar yang permanen.

\section{Hipotesis 3}

F.: Hipotesis ketiga menyatakan leverage atau hutang berkorelasi negatif dengan pembayaran deviden. Hasil pengujian menunjukkan bahwa hutang tidak berpengaruh secara signifikan terhadap dividen, artinya bahwa hutang yang diwakili oleh DER tidak berpengaruh terhadap dividen yang dibagikan perusahaan, semakin tinggi hutang maka semakin tinggi pula dividen yang 
dibagikan perusahaan. Maka hipotesis ditolak yaitu semakin tingg hutang maka semakin tinggi kemampuan perusahaan dalam pembayaran dividen.

Pada landasan teori dijelaskan bahwa perusahaan yang memiliki hutang yang rendah akan membagikan dividen yang lebih besar, namun pada kenyataannya tidak semua perusahaan yang memiliki hutang rendah akan membagikan dividen yang besar. Hal ini kemungkinan disebabkan oleh adanya perusahaan yang menambah jumlah hutang yang kemudian akan dibagikan sebagai dividen, yang bertujuan untuk menarik minat para investor agar berinvestasi pada perusahaan tersebut. Sehingga apabila banyak investor yang tertarik maka akan menguntungkan bagi perusahaan, oleh karena itu sangat dimungkinkan perusahaan yang memiliki hutang yang tinggi juga akan membagikan dividen yang tinggi pula.

\section{Hipotesis 4}

Hipotesis keempat menyatakan pertumbuhan perușahaan berkorelasi negatif dengan pembayaran deviden. Hasil pengujian menunjukkan bahwa pertumbuhan perusahaan berpengaruh secara signifikan terhadap dividen, dengan melihat taraf signifikansi yaitu sebesar 0,002 dimana nilai signifikan $0,002<0,05$, artinya bahwa pertumbuhan perusahaan yang diwakili oleh Growth berpengaruh terhadap dividen yang dibagikan perusahaan. Sedangkan hubungan yang ditunjukkan oleh koefisien regresi adalah negatif $-34,245$ artinya adalah semakin tinggi pertumbuhan perusahaan maka semakin rendah dividen yang dibagikan perusahaan. Maka hipotesis terbukti yaitu semakin tinggi pertumbuhan perusahaan maka semakin rendah kemampuan perusahaan dalam pembayaran dividen.. Pertumbuhan perusahaan membutuhkan dana yang besar, sehingga makin besar bagian dari pendapatan yang ditahan perusahaan, sehingga makin rendah dividend payout rationya

\section{Kesimpulan}

Berdasarkan analisis data dan hasil kesimpulan yang telah diuraikan pada bab sebelumnya, maka kesimpulan yang dapat diambil dari penelitian ini adalah sebagai berikut:

1. Profitabilitas terbukti secara empiris dapat memprediksi dividen yang akan dibagikan perusahaan. Tingkat profitabilitas mempunyai hubungan searah/ positif dengan dividen. Sehingga semakin tinggi profitabilitas maka semakin tinggi pula kemampuan perusahaan dalam pembayaran dividen.

2. Likuiditas tidak terbukti secara empiris dapat memprediksi dividen yang akan dibagikan perusahaan. Tingkat likuiditas mempunyai hubungan berlawanan/ negatif dengan dividen. Sehingga semakin tinggi tingkat likuiditas maka semakin rendah kemampuan perusahaan dalam pembayaran dividen. 
3. Hutang tidak terbukti secara empiris dapat memprediksi dividen yang akan dibagikan perusahaan. Tingkat hutang mempunyai hubungan searah/positif dengan dividen. Sehingga semakin tinggi tingkat hutang maka semakin tinggi kemampuan perusahaan dalam pembayaran dividen.

4. Pertumbuhan perusahaan terbukti secara empiris dapat memprediksi dividen yang akan dibagikan perusahaan. Pertumbuhan perusahaan mempunyai hubungan berlawanan/negatif dengan dividen. Sehingga semakin tinggi tingkat pertumbuhan perusahaan maka semakin rendah kemampuan perusahaan dalam pembayaran dividen.

\section{Keterbatasan, dan Saran}

Keterbatasan dari penelitian ini adalah jumlah variabel independen hanya menggunakan empat variabel, dan juga waktu penelitian yang hanya lima tahun. Sehingga disarankan untuk penelitian selanjutnya agar menambah atau mengembangkan lagi beberapa variabel atau faktor lain yang dapat mempengaruhi kemampuan perusahaan dalam pengembalian dividen.

Implikasi dari hasil penelitian ini adalah bahwa investor perlu memperhatikan tingkat profitabilitas, likuiditas, hutang, dan pertumbuhan perusahaan terhadap pengambilan keputusan investasi yang akan dilakukan. Hal ini bertujuan agar investor dapat memprediksi dividen yang akan dibagikan oleh perusahaan sehingga investor dapat mengambil keuntungan dengan melakukan antisipasi yang tepat. 
Diah Rosna Yustanti Toin \& Strisno, Analisis Investigasi Faktor-faktor yang.....

\section{Daftar Pustaka}

Brigham, Eugene F., and Louise C. Gaapenski, (1996)., Intermediate Financial Management, 5th edition, Orlando

Ernawati, (2007)., Faktor-Faktor Yang Mempengaruhi Dividen Payout Ratio Pada Perusahaan Manufaktur DI BEJ, Skripsi, Fakultas Ekonomi, Universitas Islam Indonesia, Yogyakarta

Ikatan Akuntan Indonesia, (2002)., Standar Akuntansi Keuangan, Salemba Empat, Jakarta

Lintner, John., 1956, Distribution of Incomes of Corporations Among Dividens, Retained Earnings, and Taxes, The American Economic Review, Vol. 46, No. 2, 97-113.

Mawarsari, Dhian., (2007)., Analisis Tingkat Pengembalian Investasi Saham Melalui Rasio Profitabilitas, Likuiditas, Hutang dan Pertumbuhan Perusahaan, Skripsi, Fakultas Ekonomi, Universitas Islam Indonesia, Yogyakarta

Miller, Miller., and Modigliani F (1961), 'Dividend Policy, Growth, and the Valuation of Shares'. J. Bus., 34(4): 411-433.

Modigliani F, Miller HM (1958), 'The cost of capital, corporation finance and the theory of investment'. Am. Econ. Rev., 48 (3): 261- 297.

Waskito, J. Abra., (2007)., Analisis Pengaruh Investasi, Likuiditas, Profitabilitas, dan Pertumbuhan Perusahaan Terhadap Kebijakan Devidend Payout Ratio, Skripsi, Fakultas Ekonomi, Universitas Islam Indonesia, Yogyakarta 